\title{
A cold-active acidophilic endoglucanase of Paenibacillus sp. Y2 isolated from soil in an alpine region
}

\author{
Jae Pil Lee ${ }^{1} \cdot$ Gu-Won Seo ${ }^{2} \cdot$ Shin-Deuk An ${ }^{2} \cdot$ Hoon Kim ${ }^{1,2}$ (D)
}

Received: 14 August 2017 / Accepted: 28 August 2017 / Published Online: 30 September 2017

(C) The Korean Society for Applied Biological Chemistry 2017

\begin{abstract}
A cellulolytic strain Y2 was isolated from soil obtained in the Canadian Alpine region. The isolate was identified as Paenibacillus sp. Y2 by $16 \mathrm{~S}$ rRNA sequencing. When grown in LB medium supplemented with carboxymethyl-cellulose (CMC), CMCase production increased to $122.0 \%$ of that observed in $\mathrm{LB}$ without CMC. Culture supernatant was concentrated by ultrafiltration and $80 \%$ ammonium sulfate precipitates were separated by HiTrap Q and CHT-II chromatography. The purified enzyme (EGPY2) showed a homogeneous single band and the molecular mass was estimated to be $38 \mathrm{kDa}$ by SDS-PAGE. Optimum $\mathrm{pH}$ and temperature of the enzyme were 4.5 and $30^{\circ} \mathrm{C}$, respectively. The half-life of enzyme activity at 50 was $140.7 \mathrm{~min}$, but the enzyme was drastically inactivated within $5 \mathrm{~min}$ at $55^{\circ} \mathrm{C}$. The enzyme was highly activated to 135.7 and $126.7 \%$ by $5.0 \mathrm{mM}$ of $\mathrm{Cu}^{2+}$ or $\mathrm{Mg}^{2+}$ ions, respectively, and moderately activated by $\mathrm{Ba}^{2+}$ and $\mathrm{Ca}^{2+}$ ions, whereas it was inhibited to $76.8 \%$ by $\mathrm{Fe}^{2+}$, and to $\leq 50 \%$ by $\mathrm{Mn}^{2+}, \mathrm{Co}^{2+}, \mathrm{Zn}^{2+}$, and EDTA. The enzyme was activated to $211.5 \%$ in the presence of $0.5 \mathrm{M}$ of $\mathrm{NaCl}$ and greatly tolerant to $3.15 \mathrm{M}$ of $\mathrm{NaCl}$. The enzyme showed 2.98 times higher $\beta$ glucanase activity than CMCase activity. Based on these results, it can be concluded that EG-PY2 is an acidophilic, cold-active, and halotolerant endoglucanase. The authors suggest it is considered to be useful for various industrial applications, such as, fruit juice clarification, acidic deinking processes, high-salt food processing, textile and pulp industries, and for biofuel production from seaweeds.
\end{abstract}

Hoon $\operatorname{Kim}(\bowtie)$

E-mail: hoon@sunchon.ac.kr

${ }^{1}$ Department of Pharmacy, Sunchon National University, Suncheon 57922, Republic of Korea

${ }^{2}$ Department of Agricultural Chemistry, Sunchon National University, Suncheon 57922, Republic of Korea

This is an Open Access article distributed under the terms of the Creative Commons Attribution Non-Commercial License (http://creativecommons. org/licenses/by-nc/3.0/) which permits unrestricted non-commercial use, distribution, and reproduction in any medium, provided the original work is properly cited.
Keywords Acidophilic endoglucanase - Alpine region · Coldactive $\cdot$ Halotolerant $\cdot$ Metal ion activation $\cdot$ Paenibacillus sp. Y2

\section{Introduction}

Lignocellulosic materials mainly present in the cell walls of plants and have recently attracted research attention for industrial applications in the biofuel and fine chemicals sectors (Saini et al. 2015; Álvarez et al. 2016; Kumar and Sharma 2017). Lignocellulosic materials are principally composed of cellulose, hemicellulose, and lignin. Of these, cellulose is the most abundant carbohydrate polymer, and is a homopolysaccharide composed to $\beta$-1,4-linked D-glucose polymers. Hemicellulose is the second abundant heteropolysaccharide and is largely composed of xylan, a $\beta-1,4-$ linked D-xylose, with a complex structure that has D-mannose and D-glucose in its main chains, and D-galactose, L-arabinose, and Dglucuronic acid in its branches (Álvarez et al. 2016).

Lignocellulosic materials can be broken down to fermentable sugars by microbial enzymatic hydrolysis (Mathews et al. 2015; Álvarez et al. 2016). Both fungi and bacteria have been extensively investigated for their abilities to produce novel cellulases and hemicellulases. Because of their merits, such as, high growth rates, greater complexity, multi-enzyme complexes, and their abilities to thrive in different environments, bacteria have been widely exploited for the isolation, purification, and characterization of the novel enzymes (Maki et al. 2009). Cellulolytic bacteria, especially Bacillus and Paenibacillus strains, have been isolated from various environment, such as, insect gut (Anand et al. 2010; Dantur et al. 2015), agricultural environments (Choe et al. 2008), soils and composts (Lee et al. 1999; Pason et al. 2006; Wang et al. 2008; Amore et al. 2013; Kim et al. 2016), feces (Dong et al. 2016), and forest soils (Liang et al. 2014; Kanchanadumkerng et al. 2017).

Most fungal cellulases show acidic optima, as described in a review (Ben Hmad and Gargouri 2017). However, only a few 
bacterial cellulases have been reported to be acidophilic enzymes, and cellulases from Bacillus (Blanco et al. 1998; Li et al. 2006; Zhu et al. 2011; Rawat and Tewari 2012) or Paenibacillus species (Dhar et al. 2015; Kanchanadumkerng et al. 2017) are of particular interest. On the other hand, cold-active enzymes have attracted more attention than mesophilic enzymes from the potential application standpoint because of lower limits of protein stability and short of information up to now (Kasana and Gulati 2011). Furthermore, only a few bacterial cold-active cellulases have been described, such as, Pseudoalteromonas sp., Pseudomonas sp., or Paenibacillus sp. from marine environments or feces (Zeng et al. 2006; Fu et al. 2010; Yang and Dang 2011; Dong et al. 2016), and Paenibacillus sp. from a cold lake sediment (Dhar et al. 2015). In this paper, we describe the isolation of a cellulolytic Paenibacillus sp. Y2 from Canadian Alpine soil, and biochemical characteristics of a novel acidophilic and cold-active endoglucanase. Enzyme activity activations by various cations, such as, $\mathrm{Na}^{+}, \mathrm{Cu}^{2+}$, and $\mathrm{Mg}^{2+}$ including halotolerance were also investigated.

\section{Materials and Methods}

\section{Chemicals}

Carboxymethyl-cellulose (CMC), barley $\beta$-glucan, laminarin, $p$ nitrophenyl- $\beta$-D-glucopyranoside $\quad(\mathrm{pNPG}), \quad p$-nitrophenyl- $\beta$-Dcellobioside (pNPC), birchwood xylan, 3,5-dinitrosalicylic acid (DNS), Congo red, and other chemicals were purchased from Sigma (St. Louis, MO, USA). Lichenan (Icelandic moss) was obtained from Megazyme (Wicklow, Ireland).

\section{Isolation of cellulolytic bacteria from soil}

The soil was obtained near Takakkaw Falls in the Canadian Alpine region ( $\mathrm{Na}$ et al. 2015). After serial dilutions of soil, supernatants were spread on Luria-Bertani (LB) agar plates. Colonies were tooth-picked onto LBC (LB containing 0.5\% $\mathrm{CMC}$ ) agar plates and were grown at $37{ }^{\circ} \mathrm{C}$ for $24 \mathrm{~h}$. A positive colony with the largest zone of hydrolysis on plates was selected for further studies. The isolated strain Y2 was designated Paenibacillus sp. Y2 and a sample was deposited in the Korean Collection for Type Cultures (KCTC) as KCTC 33893.

\section{Analysis of 16S rRNA}

16S rRNA was analyzed by SolGent Co. (Daejeon, Korea) and the sequence was deposited in GenBank under accession number KY744454. Sequence similarities were determined by 16S rRNA gene sequence comparisons at NCBI, i.e. http://www.ncbi.nlm. nih.gov.

\section{Production of cellulolytic enzymes}

The strain was cultivated with shaking at $200 \mathrm{rpm}$ in $200 \mathrm{~mL}$ of $\mathrm{LBC}$ in a $1 \mathrm{~L}$ flask for $24 \mathrm{~h}$ at $37^{\circ} \mathrm{C}$, and sampled every $3 \mathrm{~h}$ to observe cell growth and enzyme activity in culture supernatant.
The strain was also cultured in LB broth as a control.

\section{Enzyme purification}

After cultivation in $600 \mathrm{~mL}$ broth $(200 \mathrm{~mL} \times 3$ flasks $)$ for $24 \mathrm{~h}$, cells were harvested and supernatants were collected by centrifugation at $12,000 \times \mathrm{g}$ for $10 \mathrm{~min}$. The supernatant obtained was concentrated to $40 \mathrm{~mL}$ by ultrafiltration using a YM10 membrane (Amicon, Beverly, MA, USA) and proteins were precipitated using $80 \%$ ammonium sulfate. After dialysis against $20 \mathrm{mM}$ Tris- $\mathrm{HCl}(\mathrm{pH}$ 8.0) the crude enzyme was loaded onto a Hi-Trap Q column (5 mL, GE Healthcare, Uppsala, Sweden) and eluted with 0-1.0 M $\mathrm{NaCl}$ in $20 \mathrm{mM}$ Tris- $\mathrm{HCl}(\mathrm{pH} 8.0)$ at a flow rate of $1.0 \mathrm{~mL} / \mathrm{min}$ (Baek et al. 2017). Active fractions were collected, dialyzed against $10 \mathrm{mM}$ sodium phosphate buffer ( $\mathrm{pH}$ 6.8), and further purified by CHT-II column (5 mL, Bio-Rad, Hercules, CA, USA) chromatography with a gradient using $10-500 \mathrm{mM}$ sodium phosphate $(\mathrm{pH} 6.8)$ at a flow rate of $0.5 \mathrm{~mL} / \mathrm{min}$. Protein concentrations were determined using the Bradford method (1976) and were monitored at $\mathrm{A}_{280} \mathrm{~nm}$ during purification. SDS-PAGE was carried out using $11.5 \%$ polyacrylamide gels (Laemmli 1970), and gels were stained with Coomassie Brilliant Blue R-250.

\section{Enzyme assay}

Cellulase activity was assayed using a reaction mixture $(1.0 \mathrm{~mL})$ containing $0.5 \% \mathrm{CMC}$ and an appropriate enzyme in $50 \mathrm{mM}$ sodium citrate ( $\mathrm{pH}$ 5.0). The mixture was then heated at 50 for 30 min, and the amount of reducing sugar released was determined using the DNS method as a standard condition (Miller 1959). One unit of enzyme activity was defined as the amount of enzyme that liberated $1 \mu \mathrm{mol}$ of reducing sugar per min under these conditions.

\section{Characterization of the enzyme}

To analyze optimum temperature, enzyme activity was measured at different temperatures, 20,30, 40, 50, 55, and $60{ }^{\circ} \mathrm{C}$, and for thermostability analysis, enzyme activity was measured by preincubating the enzyme in the absence of substrate for 5, 10, 30, $60,90,120$, and $150 \mathrm{~min}$ at predetermined temperatures. To analyze optimum $\mathrm{pH}$, the enzyme was assayed between $\mathrm{pH} 3.5$ and 8.0 using $50 \mathrm{mM}$ buffers: sodium-citrate $(\mathrm{pH} 3.5-6.0)$ and sodium-phosphate ( $\mathrm{pH}$ 6.0-8.0). The influences of various cations and other entities on enzyme activity were investigated at a concentration of $5.0 \mathrm{mM}$ for $\mathrm{Na}^{+}, \mathrm{K}^{+}, \mathrm{Mg}^{2+}, \mathrm{Mn}^{2+}, \mathrm{Ca}^{2+}, \mathrm{Ba}^{2+}$, $\mathrm{Cu}^{2+}, \mathrm{Co}^{2+}, \mathrm{Fe}^{2+}, \mathrm{Zn}^{2+}$, and ethylenediaminetetraacetic acid (EDTA), and at $0.5 \%$ and $1.0 \%$ for SDS, Triton X-100, and Tween 80. For investigating the possibility of changes of thermostability in the presence of activating metal ions, the enzyme was preincubated for $60 \mathrm{~min}$ at $50{ }^{\circ} \mathrm{C}$ in the presence of each effective metal ion, and then residual activity was assayed in the standard reaction mixture and compared to residual activity of a metal ion free control. To analyze halotolerance, the enzyme was preincubated with $2.25 \mathrm{M}(13.2 \%)$ and $3.15 \mathrm{M}(18.4 \%)$ of $\mathrm{NaCl}$ at $4{ }^{\circ} \mathrm{C}$ for $24 \mathrm{~h}$, the residual activity was measured in the standard 
condition. Polysaccharides $(0.5 \%$ lichenan, barley $\beta$-glucan, laminarin, and birchwood xylan) were analyzed using the standard method described above. Modified oligosaccharides ( $2 \mathrm{mM}$ pNPG and pNPC) were assayed as described previously (Yang et al. 2017). Reaction mixtures containing xylan and lichenan were clarified by centrifugation prior to measuring absorbances.

\section{Results and Discussion}

\section{Isolation of strain and analysis of 16S rRNA}

After tooth-picked colonies were grown on LBC, a colony with the largest halo was selected and named Y2 (data not shown). The 16S rRNA sequence of the isolate Y2 showed highest similarity (99\%) with Paenibacillus amylolyticus strain NRRL NRS-290 (GenBank accession number NR_025882), P. amylolyticus strain JCM 9906 (NR_112163), Paenibacillus tundrae strain A10b (NR_044525), Paenibacillus xylanexedens strain B22a (NR_044524), and Paenibacillus tylopili strain MK2 (NR_115990) in descending order by BLAST analysis at the NCBI. Phylogenetic tree analysis showed isolate $\mathrm{Y} 2$ belongs to a group containing $P$. amylolyticus NRRL NRS-290 and P. amylolyticus JCM 9906 (Fig. 1). The isolate was named Paenibacillus sp. Y2.

\section{Cell growth and enzyme production}

Paenibacillus $s p$. Y2 showed stable CMC-hydrolyzing activity after repeated transfer (data not shown). When it was cultured in $200 \mathrm{~mL}$ of LB or LBC in a $1 \mathrm{~L}$ flask, it grew up to $18 \mathrm{~h}$ and showed similar cell growths (Fig. 2). Cellulolytic enzyme productions in LB and LBC were also similar; enzyme activity appeared after culture for $6 \mathrm{~h}$ and peaked at $21 \mathrm{~h}$. However, the maximum

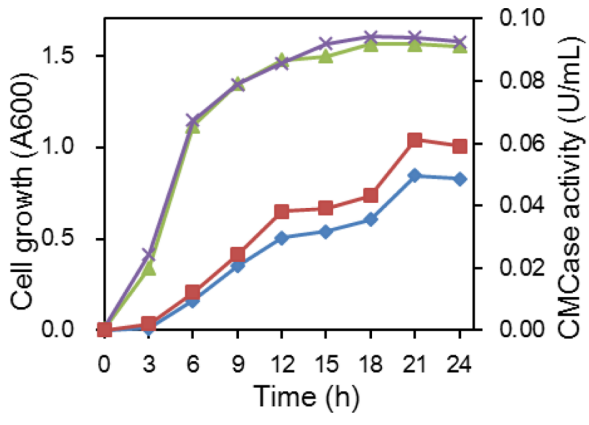

Fig. 2 Growth curves and cellulase activities of the isolate Paenibacillus sp. Y2 in LB and LBC broths. Symbols: $\boldsymbol{\Delta}$, growth in LB; $\times$, growth in $\mathrm{LBC} ; \diamond$, activity in LB; $\boldsymbol{\square}$, activity in LBC

amount of the enzyme produced in LBC was $22.0 \%$ greater than produced in LB (Fig. 2). The result suggests that CMC substrate moderately induce the productions of extracellular cellulolytic enzymes.

\section{Purification of a major extracellular cellulase}

After growing Paenibacillus sp. Y2 for $24 \mathrm{~h}$ in LBC, culture supernatant was collected by centrifugation, and a major extracellular cellulase was isolated by ultrafiltration, $80 \%$ ammonium sulfate precipitation, and Hi-Trap Q and CHT-II column chromatography. Using these methods, the cellulase was purified 9.9-fold with an enzyme activity yield of $18.9 \%$ (Table 1). SDS-PAGE showed the purified protein produced a homogeneous band and that its estimated molecular mass was $38 \mathrm{kDa}$ (Fig. 3). The enzyme was named EG-PY2. The molecular mass of EG1-PY2 was close to that of endoglucanase PgluE8 (40.4 kDa) (Dong et al. 2016), larger than that of Cel5A (33 kDa) (Cho et al. 2008), and smaller

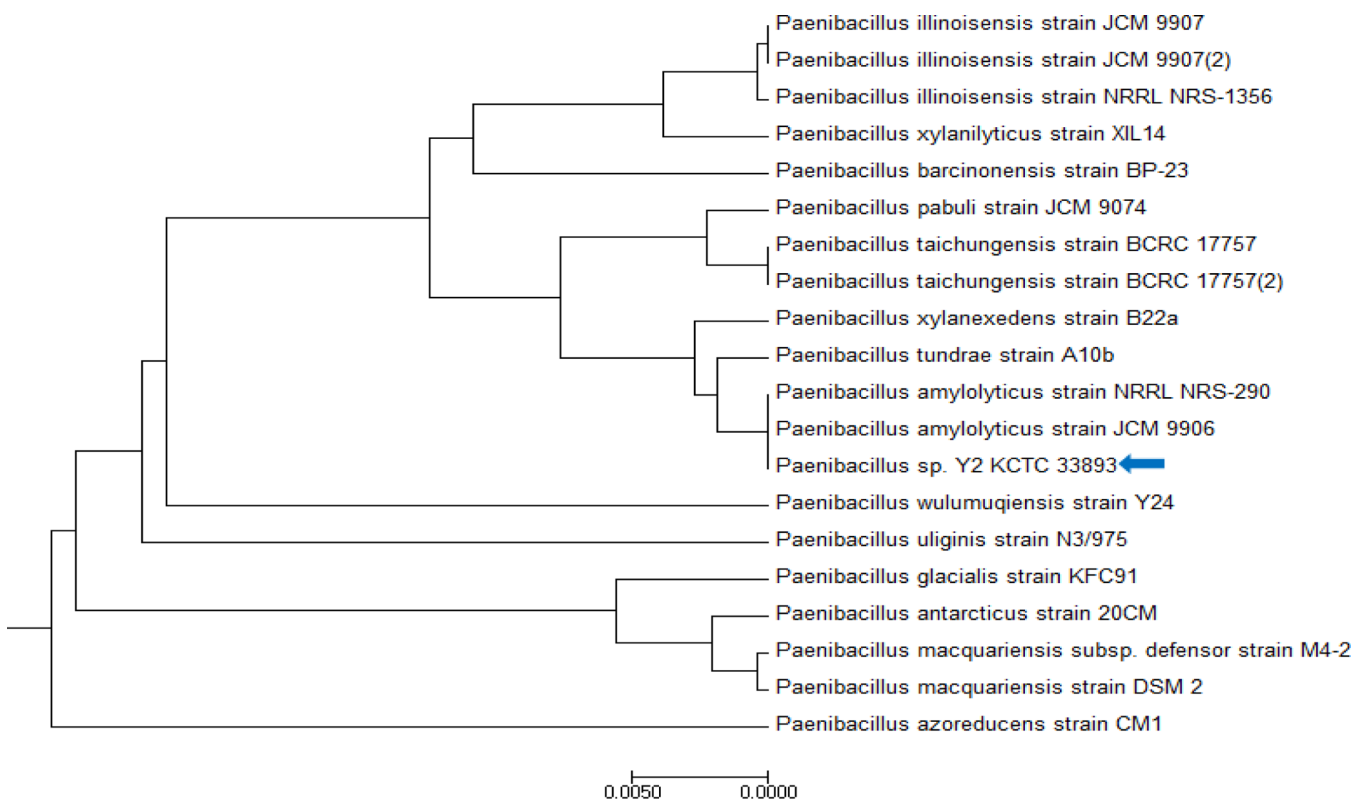

Fig. 1 Phylogenetic tree of Paenibacillus sp. Y2 
Table 1 Purification of the extracellular cellulase isolated from Paenibacillus sp. Y2

\begin{tabular}{|c|c|c|c|c|c|c|}
\hline \multirow{2}{*}{ Procedure } & Volume & Total protein & Total activity & Specific activity & Purification & Yield \\
\hline & $(\mathrm{mL})$ & $(\mathrm{mg})$ & $(\mathrm{U})$ & (U/mg) & (fold) & $(\%)$ \\
\hline Supernatant & 600.0 & 43.4 & 28.6 & 0.66 & 1.0 & - \\
\hline Ultrafiltration & 40.0 & 14.8 & 12.0 & 0.81 & 1.2 & 42.0 \\
\hline$\left(\mathrm{NH}_{4}\right)_{2} \mathrm{SO}_{4}$ precipitation & 9.0 & 8.5 & 8.8 & 1.04 & 1.6 & 30.8 \\
\hline Hi-Trap Q chromatography & 7.0 & 2.7 & 6.6 & 2.44 & 3.7 & 23.1 \\
\hline CHT-II chromatography & 8.0 & 0.83 & 5.4 & 6.52 & 9.9 & 18.9 \\
\hline
\end{tabular}

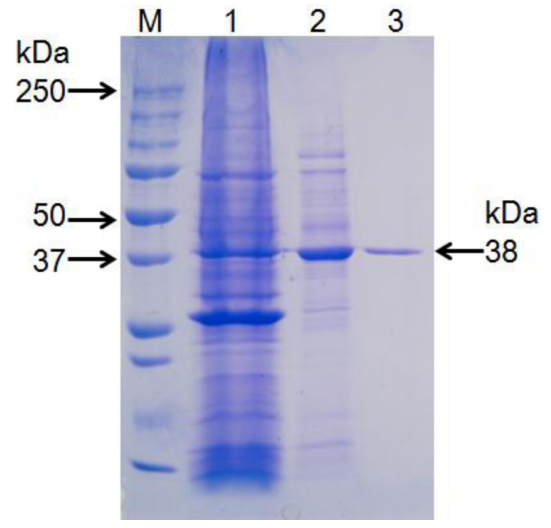

Fig. 3 SDS-PAGE result of EG-PY2. Lanes: M, size markers; 1, ammonium sulfate precipitate; 2, pool of active fractions obtained by $\mathrm{Hi}$ Trap Q chromatography; 3, pool of active fractions obtained by CHT-II chromatography. Numbers represent the molecular masses of proteins in kilodaltons $(\mathrm{kDa})$

than those of EG5C (63.5 kDa) (Dhar et al. 2015), Ce19P (60 kDa) (Fu et al. 2010), Cel5A (64 kDa) (Park et al. 2012), and Cel9P (60 kDa) (Kanchanadumkerng et al. 2017) from Paenibacillus sp. These results showed EG-PY2 is a low-molecular weight cellulase.

\section{Properties of EG-PY2}

The purified enzyme was optimally active at $\mathrm{pH} 4.5$ in sodium citrate buffer (Fig. 4A), and showed $66 \%$ and $63 \%$ of maximum activity at $\mathrm{pH} 4.0$ and 5.5, respectively. The optimum temperature of EG-PY2 was $30{ }^{\circ} \mathrm{C}$ (Fig. 4B). At 40 and $50{ }^{\circ} \mathrm{C}$, only about $10 \%$ of enzyme activity was decreased compared to the maximum activity. At $20^{\circ} \mathrm{C}$ enzyme activity was $79 \%$ of maximum activity. EG-PY2 activity decreased to 59 and $47 \%$ of its original activity after incubation for $150 \mathrm{~min}$ at 40 or $50{ }^{\circ} \mathrm{C}$, respectively (Fig. 4C), and its half-life at $50{ }^{\circ} \mathrm{C}$ was $140.7 \mathrm{~min}$. However, it was drastically inactivated after $5 \mathrm{~min}$ at $55^{\circ} \mathrm{C}$. These results suggest that EGPY2 is an acidophilic, cold-active cellulase.

The optimum $\mathrm{pH}$ of EG-PY2, that is, 4.5, was slightly higher than those, $\mathrm{pH} 4.0$, of the endoglucanases CellA from Bacillus sp., and Egl173 and CMCase from Bacillus subtilis (Blanco et al. 1998; Zhu et al. 2011; Rawat and Tewari 2012), and slightly lower than those of EG5C and CelP from Paenibacillus sp., which showed a pH optimum at 5.0 and a sharp decrease at pH 6.0 (Dhar et al. 2015; Kanchanadumkerng et al. 2017), and that of Ba-EGA
(A)

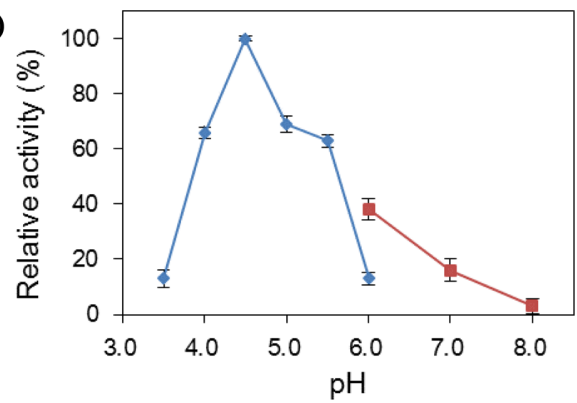

(B)

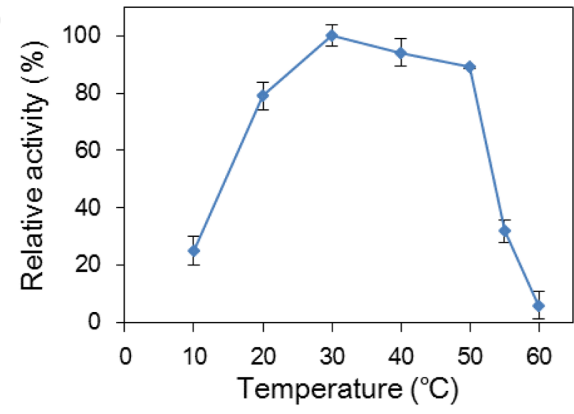

(C)

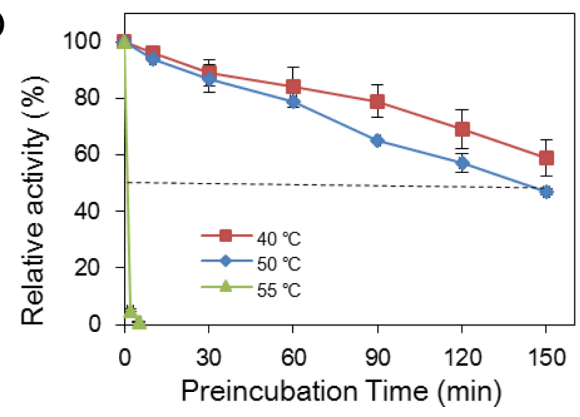

Fig. 4 Effects of $\mathrm{pH}$ (A) and temperature (B) on the activity of EG-PY2, and (C) thermal stability (C) of EG-PY2. In the thermal stability experiments, the enzyme was preincubated at temperatures for the indicated times in the absence of substrate (CMC), and then residual activity was measured in the presence of $0.5 \%$ substrate as the standard assay

(pH 4.5-6.5) from Bacillus sp. (Li et al. 2006). Acidic endoglucanases have been suggested to be practically suitable in the animal feed industry, for fruit juice clarification, paper manufacture, and nonionic-surfactant-assisted acidic deinking of old news print or old magazines (Blanco et al. 1998; Rawat and Tewari 2012).

The optimum temperature of EG-PY2 $\left(30^{\circ} \mathrm{C}\right)$ was the same as those of endoglucanase Cel5M from a deep-sea bacterium 
Table 2 Effect of cations and effectors on the activity of purified EG-PY2

\begin{tabular}{ccc}
\hline \hline Cation/effector & Concentration & Relative activity (\%) \\
\hline Control & - & $100^{*}$ \\
& $5 \mathrm{mM}$ & $111.3 \pm 3.4$ \\
$\mathrm{NaCl}$ & $50 \mathrm{mM}$ & $144.4 \pm 4.54$ \\
$\mathrm{KCl}$ & $500 \mathrm{mM}$ & $211.5 \pm 1.89$ \\
$\mathrm{MgCl}_{2}$ & $5 \mathrm{mM}$ & $103.3 \pm 10.5$ \\
$\mathrm{MnCl}_{2}$ & $5 \mathrm{mM}$ & $126.7 \pm 6.5$ \\
$\mathrm{CaCl}_{2}$ & $5 \mathrm{mM}$ & $60.4 \pm 9.2$ \\
$\mathrm{CuCl}_{2}$ & $5 \mathrm{mM}$ & $110.9 \pm 6.5$ \\
$\mathrm{CoCl}_{2}$ & $5 \mathrm{mM}$ & $135.7 \pm 1.8$ \\
$\mathrm{BaCl}_{2}$ & $5 \mathrm{mM}$ & $43.5 \pm 6.4$ \\
$\mathrm{FeCl}_{2}$ & $5 \mathrm{mM}$ & $111.9 \pm 8.1$ \\
$\mathrm{ZnCl}_{2}$ & $5 \mathrm{mM}$ & $76.8 \pm 1.2$ \\
$\mathrm{EDTA}$ & $5 \mathrm{mM}$ & $22.6 \pm 9.3$ \\
$\mathrm{SDS}$ & $5 \mathrm{mM}$ & $63.1 \pm 2.31$ \\
& $1.0 \%$ & $11.7 \pm 1.1$ \\
$\mathrm{Triton} \mathrm{X} 100$ & $2.0 \%$ & $14.9 \pm 6.9$ \\
& $1.0 \%$ & $27.8 \pm 4.4$ \\
& $2.0 \%$ & $35.0 \pm 5.7$ \\
& $1.0 \%$ & $57.7 \pm 6.6$ \\
& $2.0 \%$ & $41.4 \pm 7.2$ \\
\hline
\end{tabular}

*The value of control had a specific activity of $6.0 \mathrm{U} / \mathrm{mg}$ of protein EDTA=ethylenediaminetetraacetic acid

Pseudomonas sp. and CEL8M from a soil metagenome, however, Cel5M and CEL8M showed steep decreases in activity at either side of their optimum temperatures (Yang and Dang 2011; Bhat et al. 2013). The optimum temperature of EG-PY2 was lower than that of CelX isolated from a deep sea-bacterium Pseudoalteromonas sp. and of $\mathrm{EglC}$ isolated from a symbiotic bacterium Citrobacter farmeri (Zeng et al. 2006; Bai et al. 2016). The cold activity pattern of EG-PY2 did not change markedly between 20 and $50{ }^{\circ} \mathrm{C}$, which is similar to those reported for reasons of the endoglucanases Cel9P, EG5C and PgluE8 from Paenibacillus sp. obtained from the sea, a cold lake sediment, and feces, respectively. However, optimum temperature of the EG-PY2 was lower than those of these three endoglucanases $\left(35,40\right.$ and $50{ }^{\circ} \mathrm{C}$, respectively) (Fu et al. 2010; Dhar et al. 2015). Cold-active and acidophilic enzymes are being exploited in various fields (Kasana and Gulati 2011; Dong et al. 2016). Recently, a cold-active and acidic endoglucanase was isolated from an animal source and used to for the hydrolysis of seaweeds to produce biofuels (Song et al. 2017).

The effects of metal ions and a chelating agent on enzyme activity were investigated at a concentration $5.0 \mathrm{mM}$. EG-PY2 was highly activated to 135.7 and $126.7 \%$ by $\mathrm{Cu}^{2+}$ and $\mathrm{Mg}^{2+}$ and moderately activated by $\mathrm{Ba}^{2+}$ and $\mathrm{Ca}^{2+}$ ions, but inhibited to $76.8 \%$ by $\mathrm{Fe}^{2+}$, and to $\leq 50 \%$ by $\mathrm{Mn}^{2+}, \mathrm{Co}^{2+}$, and $\mathrm{Zn}^{2+}$ (Table 2), and EDTA reduced its activity to $63.1 \%$. EG-PY2 was activated to $211.5 \%$ in the presence of $0.5 \mathrm{M} \mathrm{NaCl}$, indicating halostimulating properties. EG-PY2 was inhibited by surfactants, although it was less sensitive to nonionic surfactants (Triton X-

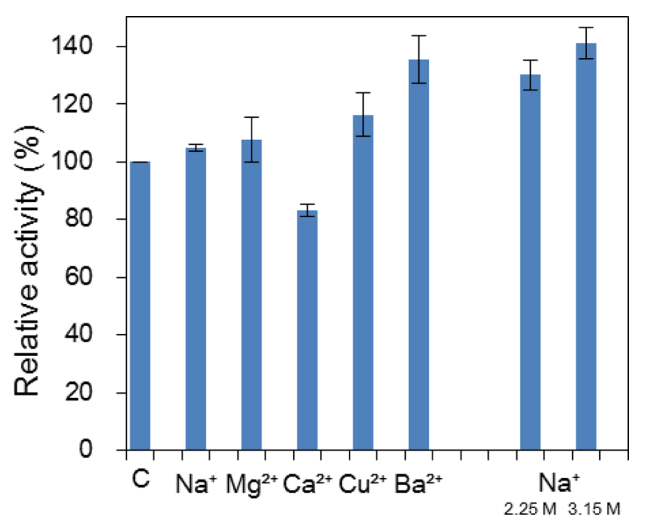

Fig. 5 Effect of metal ions on thermal stability of EG-PY2 and halotolerance by $\mathrm{NaCl}$. The enzyme was preincubated for $60 \mathrm{~min}$ at 50 ${ }^{\circ} \mathrm{C}$ in the presence of each metal ion, and then residual activity was assayed in the standard condition. For analyzing halotolerance, the enzyme was preincubated with $\mathrm{NaCl}$ for $24 \mathrm{~h}$ at $4{ }^{\circ} \mathrm{C}$, prior to the measurement of residual activity. C, Control EG-PY2 was preincubated reaction in the absence of metal ions or $\mathrm{NaCl}$

100 or Tween 80 ) than to ionic surfactant SDS (Table 2).

The effects of metal ions on endoglucanases vary considerably. Most studies on the effects of the $\mathrm{Cu}^{2+}$ ion have reported that it moderately or significantly inhibits purified endoglucanases ( $\mathrm{Li}$ et al. 2006; Fu et al. 2010; Cheng et al. 2016; Gupta et al. 2017; Kanchanadumkerng et al. 2017; Pimentel et al. 2017; Segato et al. 2017), but a few have been described enzyme activation by $\mathrm{Cu}^{2+}$ ion, mostly in Paenibacillus species (Wang et al. 2008; Park et al. 2012; Dhar et al. 2015).

The change for the enzyme thermostability by $\mathrm{Ca}^{2+}$ was not observed, and those by $\mathrm{Na}^{+}, \mathrm{Mg}^{2+}, \mathrm{Cu}^{2+}$ ions were not significant, i.e., ranged between $105-116 \%$. However, the change by $\mathrm{Ba}^{2+}$ ion was effective to be $135 \%$ compared to residual activity of a metal ion free control (Fig. 5). When the enzyme was preincubated with $2.25 \mathrm{M}(13.2 \%)$ and $3.15 \mathrm{M}(18.4 \%)$ of $\mathrm{NaCl}$, it showed 130 and $141 \%$, respectively. This indicate EG-PY2 is highly halotolerant and moreover activated. It can be used in specific processes, for example, high-salt food processing (Zhu et al. 2011; Dong et al. 2016).

The $\beta$-glucanase activity of EG-PY2 was 2.98 times greater than its CMCase activity, which suggests it hydrolyzes $\beta-1,3-1,4$ linked polymers (Table 3), similarly to endoglucanases from Paenibacillus sp. and a soil metagenome [Kanchanadumkerng et al. 2017; Pimentel et al. 2017]. But its lichenase activity was $59.0 \%$ lower than its CMCase activity. Furthermore, EG-PY2 showed little activities for laminarin, which has $\beta-1,3-1,6$ linkages, and for xylan and pNPC hydrolyzing activity. These results suggest EG-PY2 is an endo- $\beta$-1,4-glucanase and that the ratio of $1,3-$ to 1,4 linkages importantly affects its ability to hydrolyze the mixed-linked polysaccharides.

Based on the results obtained, we conclude EG-PY2 is an acidophilic, cold-active, and highly halotolerant endoglucanase. 
Table 3 Substrate specificity of EG-PY2

\begin{tabular}{ccc}
\hline \hline Substrate & Main linkage/Monomer & Relative activity (\%) \\
\hline CMC & $\beta-1,4 /$ Glucose & 100 \\
Barley $\beta$-glucan & $\beta-1,3-1,4 /$ Glucose & $298.0 \pm 7.2$ \\
Lichenan & $\beta-1,3-1,4 /$ Glucose & $59.0 \pm 1.4$ \\
Laminarin & $\beta-1,3-1,6 /$ Glucose & $10.0 \pm 2.4$ \\
Xylan & $\beta-1,4 /$ Xylose & $8.08 \pm 2.4$ \\
pNPC & & $2.0 \pm 0.8$ \\
pNPG & & $1.0 \pm 0.5$ \\
\hline
\end{tabular}

We suggest it has potential uses in acidic and low-temperature processes, such as, for fruit juice clarification, acidic deinking, high-salt food processing, textiles, pulp, and biofuel production from seaweeds.

Acknowledgments This research was partly supported by the Basic Science Research Program through the National Research Foundation of Korea funded by the Ministry of Education, Science and Technology (\#2013R1A1A4A 01013394).

\section{References}

Álvarez C, Reyes-Sosa FM, Díez B (2016) Enzymatic hydrolysis of biomass from wood. Microb Biotechnol 9: 149-156

Amore A, Pepe O, Ventorino V, Birolo L, Giangrande C, Faraco V (2013) Industrial waste based compost as a source of novel cellulolytic strains and enzymes. FEMS Microbiol Lett 339: 93-101

Anand AA, Vennison SJ, Sankar SG, Prabhu DI, Vasan PT, Raghuraman T, Geoffrey CJ, Vendan SE (2010) Isolation and characterization of bacteria from the gut of Bombyx mori that degrade cellulose, xylan, pectin and starch and their impact on digestion. J Insect Sci 10: 107

Baek SC, Ho TH, Lee HW, Jung WK, Gang HS, Kang LW, Kim H (2017) Improvement of enzyme activity of $\beta-1,3-1,4$-glucanase from Paenibacillus sp. X4 by error-prone PCR and structural insights of mutated residues. Appl Microbiol Biotechnol 101: 4073-4083

Bai X, Yuan X, Wen A, Li J, Bai Y, Shao T (2016) Cloning, expression and characterization of a cold-adapted endo-1, 4- $\beta$-glucanase from Citrobacter farmeri A1, a symbiotic bacterium of Reticulitermes labralis. PeerJ 4:e2679. eCollection 2016

Ben Hmad I, Gargouri A (2017) Neutral and alkaline cellulases: Production, engineering, and applications. J Basic Microbiol 57: 653-658

Bhat A, Riyaz-Ul-Hassan S, Ahmad N, Srivastava N, Johri S (2013) Isolation of cold-active, acidic endocellulase from Ladakh soil by functional metagenomics. Extremophiles 17: 229-239

Blanco A, Díaz P, Martínez J, Vidal T, Torres AL, Pastor FI (1998) Cloning of a new endoglucanase gene from Bacillus sp. BP-23 and characterisation of the enzyme Performance in paper manufacture from cereal straw. Appl Microbiol Biotechnol 50: 48-54

Bradford MM (1976) A rapid and sensitive method for the quantitation of microgram quantities of protein utilizing the principle of protein-dye binding Anal Biochem 72: 248-254

Cheng J, Huang S, Jiang H, Zhang Y, Li L, Wang J, Fan C (2016) Isolation and characterization of a non-specific endoglucanase from a metagenomic library of goat rumen. World J Microbiol Biotechnol 32: 12

Cho KM, Hong SJ, Math RK, Islam SM, Kim JO, Lee YH, Kim H, Yun HD (2008) Cloning of two cellulase genes from endophytic Paenibacillus polymyxa GS01 and comparison with cel 44C-man 26A. J Basic
Microbiol 48: 464-472

Dantur KI, Enrique R, Welin B, Castagnaro AP (2015) Isolation of cellulolytic bacteria from the intestine of Diatraea saccharalis larvae and evaluation of their capacity to degrade sugarcane biomass. AMB Express 5: 15

Dhar H, Kasana RC, Dutt S, Gulati A (2015) Cloning and expression of low temperature active endoglucanase EG5C from Paenibacillus sp. IHB B 3084. Int J Biol Macromol 81: 259-266

Dong M, Yang Y, Tang X, Shen J, Xu B, Li J, Wu Q, Zhou J, Ding J, Han N, $\mathrm{Mu} \mathrm{Y}$, Huang Z (2016) NaCl-, protease-tolerant and cold-active endoglucanase from Paenibacillus sp. YD236 isolated from the feces of Bos frontalis. Springerplus 5: 746

Fu X, Liu P, Lin L, Hong Y, Huang X, Meng X, Liu Z (2010) A novel endoglucanase (Ce19P) from a marine bacterium Paenibacillus sp. BME14. Appl Biochem Biotechnol 160: 1627-1636

Gupta P, Mishra AK, Vakhlu J (2017) Cloning and characterization of thermoalkalistable and surfactant stable endoglucanase from Puga hot spring metagenome of Ladakh (J\&K). Int J Biol Macromol 103: 870-877

Kanchanadumkerng P, Sakka M, Sakka K, Wiwat C (2017) Characterization of endoglucanase from Paenibacillus sp. M33, a novel isolate from a freshwater swamp forest. J Basic Microbiol 57: 121-131

Kasana RC, Gulati A (2011) Cellulases from psychrophilic microorganisms: a review. J Basic Microbiol 51: 572-579

Kim MS, Woo MH, Chang YH, Chung N, Kim JS (2016) Biochemical characterization of a noble xylanase from Paenibacillus sp. EC116. Appl Biol Chem 59:313-320

Kumar AK, Sharma S (2017) Recent updates on different methods of pretreatment of lignocellulosic feedstocks: a review. Bioresour Bioprocess 4: 7

Laemmli UK (1970) Cleavage of structural proteins during the assembly of the head of bacteriophage T4. Nature 227: 680-685

Lee KD, Kim J, Kim H (1999) Purification and characterization of carboxymethyl-cellulase produced by Bacillus sp. KD1014. Agric Chem Biotechnol 42: 107-112

Li YH, Ding M, Wang J, Xu GJ, Zhao F (2006) A novel thermoacidophilic endoglucanase, Ba-EGA, from a new cellulose-degrading bacterium, Bacillus sp. AC-1. Appl Microbiol Biotechnol 70: 430-436

Liang YL, Zhang Z, Wu M, Wu Y, Feng JX (2014) Isolation, screening, and identification of cellulolytic bacteria from natural reserves in the subtropical region of China and optimization of cellulase production by Paenibacillus terrae ME27-1. Biomed Res Int 2014: 512497

Maki M, Leung KT, Qin W (2009) The prospects of cellulase-producing bacteria for the bioconversion of lignocellulosic biomass. Int J Biol Sci 5: 500-516

Mathews SL, Pawlak J, Grunden AM (2015) Bacterial biodegradation and bioconversion of industrial lignocellulosic streams. Appl Microbiol Biotechnol 99: 2939-2954

Miller GL (1959) Use of dinitrosalicylic acid reagent for determination of reducing sugar. Anal Chem 31: 426-428

Na HB, Jung WK, Jeong YS, Kim HJ, Kim SK, Kim J, Yun HD, Lee JK, Kim H (2015) Characterization of a GH family $8 \beta$-1,3-1,4-glucanase with distinctive broad substrate specificity from Paenibacillus sp. X4. Biotechnol Lett 37: 643-655. Erratum in: Biotechnol Lett 37: 657-658

Park IH, Chang J, Lee YS, Fang SJ, Choi YL (2012) Gene cloning of endoglucanase Cel5A from cellulose-degrading Paenibacillus xylanilyticus $\mathrm{KJ}-03$ and purification and characterization of the recombinant enzyme. Protein J 31: 238-245

Pason P, Kyu KL, Ratanakhanokchai K (2006) Paenibacillus curdlanolyticus strain B-6 xylanolytic-cellulolytic enzyme system that degrades insoluble polysaccharides. Appl Environ Microbiol 72: 2483-2490

Pimentel AC, Ematsu GC, Liberato MV, Paixão DA, Franco Cairo JP, Mandelli F, Tramontina R, Gandin CA, de Oliveira Neto M, Squina FM, Alvarez TM (2017) Biochemical and biophysical properties of a metagenome-derived GH5 endoglucanase displaying an unconventional domain architecture. Int J Biol Macromol 99: 384-393 
Rawat R, Tewari L (2012) Purification and characterization of an acidothermophilic cellulase enzyme produced by Bacillus subtilis strain LFS3. Extremophiles 16: 637-644

Saini A, Aggarwal NK, Sharma A, Yadav A (2015) Prospects for Irradiation in Cellulosic Ethanol Production. Biotechnol Res Int 2015: 157139

Segato F, Dias B, Berto GL, de Oliveira DM, De Souza FH, Citadini AP, Murakami MT, Damásio AR, Squina FM, Polikarpov I (2017) Cloning, heterologous expression and biochemical characterization of a nonspecific endoglucanase family 12 from Aspergillus terreus NIH2624. Biochim Biophys Acta 1865: 395-403

Song JM, Hong SK, An YJ, Kang MH, Hong KH, Lee YH, Cha SS (2017) Genetic and structural characterization of a thermo-tolerant, cold-active, and acidic endo- $\beta$-1,4-glucanase from antarctic springtail, Cryptopygus antarcticus. J Agric Food Chem 65: 1630-1640

Wang CM, Shyu CL, Ho SP, Chiou SH (2008) Characterization of a novel thermophilic, cellulose-degrading bacterium Paenibacillus sp. strain B39. Lett Appl Microbiol 47: 46-53

Yang J, Dang H (2011) Cloning and characterization of a novel cold-active endoglucanase establishing a new subfamily of glycosyl hydrolase family 5 from a psychrophilic deep-sea bacterium. FEMS Microbiol Lett 325: 71-76

Yang MJ, Lee HW, Kim H (2017) Enhancement of thermostability of Bacillus subtilis endoglucanase by error-prone PCR and DNA shuffling. Appl Biol Chem 60: 73-78

Zeng R, Xiong P, Wen J (2006) Characterization and gene cloning of a coldactive cellulase from a deep-sea psychrotrophic bacterium Pseudoalteromonas sp. DY3. Extremophiles 10: 79-82

Zhu C, Xu Z, Song R (2011) The endoglucanase from Bacillus subtilis BEC-1 bears halo-tolerant, acidophilic and dithiothreitol-stimulated enzyme activity. World J Microbiol Biotechnol 27: 2863-2871 